\title{
Clinical forms of granulomatosis with polyangiitis
}

\section{Postacie kliniczne ziarniniakowatości z zapaleniem naczyń}

\author{
Marta Madej ${ }^{1,2}$, Agnieszka Matuszewska ${ }^{3}$, Katarzyna Białowąs $^{1}$, Piotr Wiland ${ }^{1,2}$ \\ ${ }^{1}$ Department and Clinic of Rheumatology and Internal Medicine, Wroclaw Medical University, Poland \\ ${ }^{2}$ Clinic of Rheumatology and Internal Medicine, University Clinical Hospital, Wroclaw, Poland \\ ${ }^{3}$ Department of Pharmacology, Wroclaw Medical University, Poland
}

Key words: granulomatosis with polyangiitis, ANCA antibody, pulmonary-renal syndrome.

Słowa kluczowe: ziarniniakowatość z zapaleniem naczyń, przeciwciała ANCA, zespół płucno-nerkowy.

\begin{abstract}
Sum mary
Granulomatosis with polyangitis (GPA) is one of systemic connective tissue diseases. Necrotizing vasculitis affects small- and medium-sized vessels. Antineutrophil cytoplasmic antibodies directed against the neutrophil serine protease proteinase-3 (CANCA, PR3-ANCA) have been identified in approximately $80-95 \%$ of patients with GPA. In typical cases upper and lower respiratory tract and kidneys are involved. However GPA produce a broad spectrum of clinical symptomes, that includes: ocular and ear involvement, peripheral and central nervous system manifestations, heart and digestive tract involvement. The diffuse alveolar hemorrhage and pulmonary-renal syndrome may also occur.

The diagnosis of granulomatosis with polyangiitis may cause many difficulties, specially in cases with limited organ involvement, with untypical spectrum of clinical features and in ANCA-negative patients. We attempt to present differential diagnosis of GPA in this review article.
\end{abstract}

\section{Introduction}

Granulomatosis with polyangiitis (GPA) is a systemic disease of an autoimmune background. According to different sources its incidence ranges from 3 to 16 cases per 100,000 inhabitants [1]. A necrotic inflammatory process is mainly observed in small and middle size vessels (venous, arterial vessels and capillaries) [2]. Clinical symptoms include upper and lower respiratory tract symptoms as well as kidney symptoms. However, a spectrum of clinical manifestations of this disease is wider and includes central and peripheral nervous system, ear, eye, skin and oral mucosa, joints, heart, gastrointestinal tract and other

\section{Streszczenie}

Ziarniniakowatość z zapaleniem naczyń (GPA) należy do układowych chorób tkanki łącznej. Martwiczym procesem zapalnym objęte są małe i średnie naczynia krwionośne. U 80-95\% pacjentów stwierdza się obecność przeciwciał skierowanych przeciwko proteinazie 3 (CANCA, PR3-ANCA). W typowym przebiegu choroby opisuje się występowanie zmian w górnych i dolnych drogach oddechowych oraz w nerkach. Symptomatologia schorzenia jest jednak szeroka. Obejmuje m.in. zajęcie narządu wzroku, słuchu, ośrodkowego i obwodowego układu nerwowego, serca czy przewodu pokarmowego. W przebiegu choroby może także wystąpić rozlane krwawienie pęcherzykowe i zespół płucno-nerkowy.

Rozpoznanie ziarniniakowatości z zapaleniem naczyń może stwarzać liczne trudności diagnostyczne, szczególnie w przypadkach z ograniczonymi zmianami narządowymi, o nietypowym przebiegu lub w postaciach seronegatywnych. W niniejszej pracy przedstawiono diagnostykę różnicową tego schorzenia.

organs. The presence of antineutrophil cytoplasmic antibodies (ANCA) is a significant component of the disease manifestation. In 80-95\% of patients ANCA against proteinase 3 (CANCA, PR3-ANCA) are observed, whereas more rarely (in $5-20 \%$ of patients) ANCA against myeloperoxidase (pANCA, MPO-ANCA) can be observed [3]. Taking into account a clinical picture there are five forms of GPA: - limited form - lesions in upper and/or lower respiratory tract, without other organ lesions, and without general symptoms,

- early systemic form - other systemic lesions are present compared to a limited form, but without organ-threatening symptoms or life-threatening symptoms,

Address for correspondence:

Marta Madej, PhD, Department and Clinic of Rheumatology and Internal Medicine, Wroclaw Medical University, Borowska 213,

50-556 Wroclaw, e-mail: marta.madej@poczta.fm

Submitted: 25.09.2014 
- generalized form - with symptoms of organ-threatening failure (creatinine levels $<5.6 \mathrm{mg} / \mathrm{dl}$ ),

- severe generalized form - with symptoms of renal failure (creatinine levels $>5.6 \mathrm{mg} / \mathrm{dl}$ ) or other organ failure,

- resistant to treatment form.

Due to a varied clinical picture it is difficult to make a diagnosis especially in cases with limited organ lesions, with an atypical course or in seronegative forms (ANCAnegative) that account for up to $20 \%$ of cases [4]. Additionally, in the case of forms with a characteristic organ triad (upper respiratory tract symptoms, pulmonary lesions and glomerulonephritis) it is necessary to exclude other potential reasons for the presence of such symptoms. It is necessary to perform broad-spectrum diagnostic tests taking into account other forms of vasculitis (including drug-induced reactions), systemic connective tissue diseases, proliferative or infectious diseases. The final diagnosis is made based on a clinical picture, histopathological findings and immune diagnostic tests.

\section{Localized granulomatosis with polyangiitis - diagnostic problems}

\section{Upper respiratory tract disease}

Sinusitis is the most common symptom associated with GPA. It is present in approx. $70 \%$ of patients at an early stage of disease [5]. Impaired nasal patency, purulent or purulent-bloody nasal discharge is typical. In many cases the initial diagnosis is infection. Due to lack of improvement after routine therapy (including many antibiotics) a diagnosis is often reconsidered. With regard to a macroscopic picture GPA is associated with swelling and ulcerative-necrotic foci on the nasal mucosa, sinuses, oral cavity and throat, with a tendency for extravasations. The cartilage and bone structures may be damaged, the nasal septum might become perforated, and then the ridge of the nose may subside (saddle nose) [6]. On the other hand, nasal polyps are typically not observed, as they are more typical of eosinophilic granulomatosis with polyangiitis (EGPA, formerly known as Churg-Strauss syndrome). In order to make a diagnosis of GPA, it is advised to perform a detailed ENT (ear, nose and throat) examination with endoscopy of the nose and paranasal sinuses. At that time it is recommended to collect a sample for a histopathological examination from the granulation tissue and pathological tissue that has been visualized. Imaging tests, computed tomography above all, are also beneficial with regard to diagnostics. In patients with chronic sinusitis serous otitis and hearing impairment may develop. Table I presents a differential diagnosis of conditions associated with symptoms limited to the upper respiratory tract.

Cocaine-induced midline destructive lesions (CIM$\mathrm{DL}$ ) may imitate GPA. Their location is associated with a route of administration, and typical lesions include nasal septal perforation, destructive lesions of the bones (of the sinuses, palate) [7]. This disease is associated with positive anti-elastase antibodies HNE-ANCA (a differentiating factor for GPA), with a perinuclear staining pattern (pANCA). Additionally, antibodies against other antigens are present, like proteinase-3 (PR3-ANCA) [8]. Advanced local lesions are not accompanied by organ complications, and systemic symptoms are mild. Additionally, a weak reaction or no reaction to immunosuppression is typical.

Granulomatosis with polyangiitis may also involve the larynx, with signs of cough, dyspnea and stridor. Laryngoscopy reveals edema of the mucosa, its reddening and/or subglottic stenosis [9].

Table I. Differential diagnosis of the upper respiratory tract symptoms

\begin{tabular}{|c|c|}
\hline Symptom & Differential diagnosis \\
\hline gingival hyperplasia & $\begin{array}{l}\text { acute or chronic infectious gingival inflammation, drug-induced reactions (cyclosporine A, pheny- } \\
\text { toin, calcium channel blockers), Crohn's disease, leukemia (acute monocytic and myelomonocytic } \\
\text { leukemia, among others), polyarteritis nodosa, Churg-Strauss syndrome, gingival tumors, peripheral } \\
\text { ameloblastoma, pyogenic granuloma, peripheral giant cell granuloma }\end{array}$ \\
\hline $\begin{array}{l}\text { inflammatory-ulcera- } \\
\text { tive lesions of the oral } \\
\text { mucous membrane }\end{array}$ & $\begin{array}{l}\text { systemic lupus erythematosus, Behçet's disease, agranulocytosis, neutropenia, Crohn's disease, } \\
\text { leukemia, tuberculosis, syphilis, HIV infection }\end{array}$ \\
\hline chronic sinusitis & infections, Churg-Strauss syndrome, sarcoidosis, neoplasms, cocaine use \\
\hline nasal bleeding & $\begin{array}{l}\text { infectious inflammatory diseases of the nasal mucosa, dried nasal mucosa, neoplasms, blood coagu- } \\
\text { lation disturbances (also drug-induced), traumas, intoxication and direct irritation by chemical sub- } \\
\text { stances, vascular diseases (for example, Osler-Weber-Rendu disease), deficiency of vitamins C, K, D }\end{array}$ \\
\hline hoarse voice & $\begin{array}{l}\text { damage to the vocal cords or laryngeal muscles (e.g. myasthenia gravis, chronic use of inhaled glu- } \\
\text { cocorticosteroids), damage to the nerves innervating the laryngeal muscles (e.g. after strumectomy), } \\
\text { local lesions e.g. laryngeal cancer }\end{array}$ \\
\hline
\end{tabular}


Table II. Differential diagnosis of the pulmonary symptoms related to granulomatosis with polyangiitis

\begin{tabular}{|ll|}
\hline Symptom & \multicolumn{1}{c|}{ Differential diagnosis } \\
\hline chronic cough & $\begin{array}{l}\text { viral, bacterial, fungal infections of the paranasal sinuses, bronchi, lungs, lung cancer, } \\
\text { pulmonary interstitial diseases, chronic obstructive pulmonary disease, bronchial asthma, } \\
\text { bronchiectasia, cystic fibrosis, drug-induced (ACE inhibitors) left ventricular heart failure, } \\
\text { gastroesophageal reflux }\end{array}$ \\
\hline purulent sputum & bronchitis, bronchiectasia, pneumonia \\
\hline hemoptysis & $\begin{array}{l}\text { lung cancer (e.g. squamous epithelial cancer located centrally), bronchitis, bronchiectasia } \\
\text { pneumonia (bacterial, fungal), tuberculosis, pulmonary embolism, left ventricular heart } \\
\text { failure, pulmonary hypertension other than associated with GPA, vasculitis, SLE, disease } \\
\text { associated with anti-basement membrane antibodies, use of acetylsalicylic acid, vitamin K } \\
\text { antagonists, fibrinolytics, cocaine }\end{array}$ \\
\hline pleural pain & pneumonia, pleuritis, pulmonary embolism \\
\hline $\begin{array}{l}\text { nodular consolidations or infiltra- } \\
\text { tions visible in a lung X-ray }\end{array}$ & $\begin{array}{l}\text { abscess, tuberculoma, fungal lesions, cancer, RA, sarcoidosis, amyloidosis, bronchiolitis, } \\
\text { lung infarct, pneumoconiosis, congenital or parasitic cyst }\end{array}$ \\
\hline pleural effusion & pneumonia, tuberculosis, cancer, RA, SLE \\
\hline $\begin{array}{l}\text { enlarged lymph nodes in the } \\
\text { mediastinum and pulmonary hila }\end{array}$ & $\begin{array}{l}\text { infections, sarcoidosis, lymphatic system cancers } \\
\text { metastases of solid organ cancers e.g. lung cancer, breast cancer } \\
\text { SLE, RA, mixed connective tissue disease, dermatomyositis, Sjögren's syndrome }\end{array}$ \\
\hline
\end{tabular}

Gingival hypertrophy is a rare symptom observed in patients with GPA. These lesions may be observed as early as at the initial stage of the disease [10], or may even precede organ lesions by several weeks or months [11]. The gingiva from the labial and buccal side are enlarged, soft, granulomatous, bleed easily, therefore the whole picture is called hyperplastic granulomatous strawberry-like gingiva [12]. A patient with hyperplastic gingiva should be examined by a dental surgeon in order to exclude infection as a cause of such lesions. A medical history should include treatment applied, hormonal disturbances as well as gastrointestinal disturbances. It is also necessary to perform routine laboratory tests such as ESR, CBC with a smear and protein electrophoresis. In doubtful cases a gingival biopsy may be indicated (suspected neoplastic lesions).

\section{Lower respiratory tract disease}

Pulmonary lesions at an initial stage of GPA are present in half of patients [13]. They may manifest as cough, hemoptysis, dyspnea, chest discomfort or may be asymptomatic [14]. A radiological picture may vary. The most typical are single or numerous nodules with the diameter up to $10 \mathrm{~cm}$, often decomposing forming cavities [15]. Additionally, parenchymal consolidations and ground-glass opacity lesions caused by intra-alveolar hemorrhages in the lungs may be visible $[16,17]$. More rarely observed complications include: effusion in the pleural cavity, enlarged lymph nodes in the mediastinum and pulmonary hila.

Patients with GPA may also develop a stenosis and/ or softening of the trachea and bronchi, and tracheoesophageal fistulas. In such cases it is necessary to pay special attention to symptoms of respiratory tract obstruction and infective complications.

A differential diagnosis of lesions limited to the lower respiratory tract (Table II) should include imaging tests, bronchoscopy (with bronchoalveolar lavage - BAL), lung function tests as well as serological and bacteriological tests. High-resolution computed tomography (HRCT) is a tool of significant importance as it enables to evaluate the size, morphology and location of lesions precisely, as well as to assess their evolution in time. In patients with granulomatosis with polyangiitis bronchoscopy may visualize ulcerative bronchial mucositis, post-inflammatory stenoses and fistulas. Lung function tests indicate obstruction, less frequently restriction with reduced carbon monoxide diffusing capacity [13].

Presence of eosinophils and asthma is typical of EGPA. In patients in whom disease is associated with anti-glomerular basement membrane antibodies (Goodpasture's disease) these antibodies are present (in 80$90 \%$ of patients).

\section{Limited form with ophthalmic features}

Inflammatory lesions due to GPA may involve all structures of the eye. In some patients ocular symptoms may be the only clinical symptoms observed. In the case of patients with GPA symptoms of ocular involvement are significantly more frequent than in the case of small-vessel vasculitis: EGPA or microscopic polyangiitis (MPA). According to the literature inflammatory lesions of the eye are observed in 29-57\% of patients with GPA [18]. Isolated ocular lesions were observed on diagnosis in $15 \%$ of patients [18]. 
A clinical picture of inflammatory lesions in the eye can vary and may have a form of: inflammation of the episclera and sclera, conjunctivitis, inflammation of the nasolacrimal duct, cornea, visual acuity disturbances, anterior and posterior uveitis. A sudden loss of vision or optical nerve neuropathy are observed more rarely. $\mathrm{Pa}$ ralysis of the oculomotor nerves that is more frequently observed in GPA may be secondary to intraorbital infiltration. All described lesions are also present in other types of small-vessel vasculitis as well as in polyarteritis nodosa (PAN), but with a significantly lower incidence. A clinical picture of so called red eye may be highly different with regard to its etiology (conjunctivitis vs. scleritis), course and consequences, and it might even include severe ocular damage.

A typical symptom of GPA includes inflammatory infiltrations inside the orbital cavity, consistent with orbital pseudotumor. The inflammatory process may originate directly from the nasal cavity, paranasal sinuses, dura mater or it may be a result of proliferation of inflammatory granulation tissue located inside the orbital cavity. Results of observational studies have indicated that orbital infiltration is associated with treatment resistance, a higher risk of recurrence, predisposition for local destructive lesions and a complete vision loss (even in $19 \%$ of patients) [4]. Taking into account how inflammatory lesions are spread in the course of GPA, a biopsy of the mucous membrane of the nose or paranasal sinuses combined with magnetic resonance imaging (MRI) or computed tomography (CT) may be an important element of diagnostic tests (including a differential diagnosis) of ocular lesions [19].

\section{Organ lesions in the course of granulomatosis with polyangiitis}

Due to diversity of symptoms associated with GPA patients present at physicians of various specializations. Involvement of the kidneys, heart (exudative pericarditis, angina pectoris), central and peripheral nervous system has to be differentiated against other forms of vasculitis, especially small-vessel vasculitis as well as polyarteritis nodosa and other systemic connective tissue diseases. With regard to their morphology skin lesions are not characteristic, may be observed in the majority of forms of vasculitis, and they include palpable purpura, papules, subcutaneous nodules, necrotic lesions. Histopathological findings associated with skin lesions observed in GPA are also not typical. Articular lesions in patients with GPA are more often associated with arthralgia than arthritis. Monoarthritis or oligoarthritis might develop (symmetric polyarthritis is observed rarely). In these cases joint damage is not observed, contrary to rheumatoid arthritis (RA). Forms with fever have to be differentiated with infections, proliferative diseases of the lymphatic system, especially if lymphadenopathy is present.

Organ lesions that are rarely present in GPA have to be differentiated with special caution. This group of symptoms includes for example involvement of the parotid glands observed in 1-4\% of patients [20]. Lesions are observed in men with a slightly higher incidence (60\% vs. $40 \%$ ) and are associated with facial nerve paralysis. The parotid glands are infiltrated the most frequently, but the inflammation may also include the submandibular and sublingual glands, but it is observed significantly more rarely in these locations [21]. Histopathological findings are usually consistent with unspecific inflammation. Other rarer locations of GPA include: inflammatory lesions of the urogenital tract (prostatitis, testitis, epididymitis, ovaritis), gastrointestinal involvement consistent with pancreatitis (pseudotumor, acute pancreatitis), hepatic involvement and breast inflammation [22-24].

\section{Granulomatosis with polyangiitis histopathological findings}

A histopathological examination is necessary in order to diagnose GPA for certain. A microscopic picture reveals the presence of granulomas, fibrotic necrosis and inflammatory lesions in the walls of the blood vessels [6, 13]. Inflammatory lesions consist of plasma cells, lymphoid cells, histiocytes and granulocytes [25]. Granulomas are formed in the perivascular space, and more rarely, in the vascular wall [13].

The upper respiratory tract is the easiest location with regard to collecting histopathological specimens. A procedure of collecting specimens from this area is a relatively low invasive procedure and associated with a low risk of complications. However, a biopsy specimen collected this way may not be suitable for diagnostic purposes due to an atypical histopathological picture or too small a sample obtained making it impossible to confirm the diagnosis for certain. A biopsy specimen is often collected from the area of the sinuses and nose, and less frequently, from the middle ear. Biopsies of the subglottic area are associated with a risk of complications (scarring) [26]. In specific cases it may be necessary to perform a biopsy of the lung tissue or kidneys. With regard to renal biopsy specimens collected in GPA or in other forms of vasculitis associated with ANCA immunoglobulin deposits are not observed or they are scarce (pauci-immune glomerulonephritis), what is an important feature for a differential diagnosis. A biopsy specimen from the lung tissue where pathological lesions are observed is of the highest diagnostic value [3]. 


\section{Pulmonary-renal syndrome and diffuse alveolar hemorrhage in granulomatosis with polyangiitis - differential diagnosis}

Pulmonary-renal syndrome (PRS) manifests with diffuse hemorrhage of various intensity present in the alveoli, and coexisting with glomerulonephritis. The mortality rate in PRS may reach even 25-50\%, depending on its etiology [27]. The most common causes of pulmonary-renal syndrome include small-vessel vasculitis associated wih ANCA, Goodpasture's disease and systemic lupus erythematosus (SLE) [27, 28]. Pulmonary-renal syndrome in vasculitis without ANCA is rarely observed, and it includes IgA-associatd vasculitis (Henoch-Schönlein purpura) or Behçet's disease. An analysis of the etiology of pulmonary-renal syndrome in patients treated at the intensive care units has demonstrated that PRS with pANCA is observed the most frequently (39\%), followed by cANCA (27.5\%) and pANCA/anti-GBM (14.3\%), other conditions of a varied etiology account for $28 \%$ [29]. There are reports on cases of PRS coexisting with ANCA (CANCA and PANCA) but without any other clinical features of vasculitis that may correspond to limited forms of GPA or microscopic polyangiitis. A differential diagnosis should also include drug-induced pulmonary-renal syndrome associated with ANCA. Agents that might induce PRS include, among others, allopurinol, sulfasalazine, propylthiouracil. pANCA are observed more frequently than cANCA. Drug-induced PRS has usually a milder course and a good prognosis. Isolated diffuse alveolar hemorrhage may be the only symptom of localized granulomatosis with polyangitis. Etiological factors associated with PRS are presented in Table III.

\section{General rules for granulomatosis with polyangiitis treatment}

The treatment is aimed to achieve remission, namely lack of clinical factors of active disease. It includes re- mission induction and maintenance treatment. Pharmacotherapy in GPA is varied and depends on a clinical disease form (that has been defined above). Glucocorticosteroids (GS) and e.g. methotrexate (MTX) are used to treat localized and early systemic forms. A generalized form requires more intensive treatment. In these cases treatment of choice includes cyclophosphamide (CFS) administered in intravenous infusions, less frequently oral administrated, combined with high-dose GS. Despite the fact that the efficacy of CFS treatment is similar irrespective of the route of administration, intravenous treatment is preferred, due to a lower risk of complications, above all [30]. Rituximab (RTX, mouse-human chimeric antibody to CD20) may be an alternative to CFS [31]. Its use is justified in specific groups of patients, for example in women of childbearing potential in whom CFS treatment may be associated with a risk of infertility. RTX is used to treat forms resistant to CFS treatment, forms with involvement of the kidneys, respiratory tract or the eye.

Another issue is therapy in cases with resistance to treatment. When resistance to treatment is considered it is necessary to exclude lack of efficacy as a result of too low doses of medicines. Agents used in the treatment of CFS-resistant forms include: RTX that has already been mentioned, mycophenolate mofetil, intravenous immunoglobulins. The status of TNF- $\alpha$ inhibitors in the GPA treatment is not clear. The WGET study (the Wegener's Granulomatosis Etanercept Trial) on the use of etanercept in patients with GPA has demonstrated a higher risk of cancer in patients receiving this agent $[32,33]$. On the other hand, infliximab seems to be effective and safe in the treatment of resistant GPA forms [34]. The most recent reports suggest that abatacept is also effective, but further studies are necessary [35].

Local complications (subglottic stenosis, saddle nose) are in many cases associated with invasive procedures (endoscopic procedures, local administration of

Table III. Causes of pulmonary-renal syndrome

\begin{tabular}{|c|c|}
\hline Etiology of pulmonary-renal syndrome & Cause \\
\hline vasculitis associated with ANCA & $\begin{array}{l}\text { granulomatosis with polyangiitis } \\
\text { microscopic vasculitis } \\
\text { eonosinophilic granulomatosis with polyangiitis }\end{array}$ \\
\hline immune complex-associated vasculitis & $\begin{array}{l}\text { anti-glomerular basement membrane (anti-GBM) disease, Ig-A-vasculitis, } \\
\text { cryoglobulinemic vasculitis, IgA nephropathy }\end{array}$ \\
\hline other systemic vasculitis & Behçet's disease \\
\hline systemic connective tissue diseases & $\begin{array}{l}\text { systemic lupus erythematosus, systemic sclerosis, rheumatoid arthritis, mixed } \\
\text { connective tissue disease, antiphospholipid syndrome }\end{array}$ \\
\hline drug-induced ANCA-associated vasculitis & sulfasalazine, allopurinol, hydralazine, propylthiouracil, D-penicillamine \\
\hline other & cancers, infections, thrombotic thrombocytopenic purpura \\
\hline
\end{tabular}


$\mathrm{GC}$, reconstructive treatment). A subglottic stenosis that is a complication of local inflammation usually poorly responds to systemic immunosuppressive treatment. There are single reports on the use of radiation therapy in the treatment of lesions located in the upper respiratory tract that are resistant to standard therapy [36]. However, it is not a strategy with efficacy that has been unanimously confirmed.

Maintenance treatment usually includes the following drugs: methotrexate, azathioprine, mycophenolate mofetil, leflunomide, more rarely, RTX. Duration of maintenance treatment has not been determined unanimously and it may be necessary to maintain remission even for 2 years [13].

\section{Summary}

Various symptoms of GPA, especially in cases where typical clinical symptoms and immune disturbances are present, are usually not associated with diagnostic problems. Cases with an atypical course, with organic lesions located in only one organ, as it can be observed at an early stage of disease, are a clinical problem. Misdiagnosis and delayed treatment start may lead to serious consequences. Therefore it is necessary to monitor patients carefully, especially in cases with an atypical course, in order to verify the diagnosis, to monitor complications of the disease itself, and to monitor drug adverse reactions.

The authors declare no conflict of interest.

\section{References}

1. Morales-Angulo C, García-Zornoza R, Obeso-Agüera S, et al. Ear, nose and throat manifestations of Wegener's granulomatosis (granulomatosis with polyangitis). Acta Otorrinolaringol Esp 2012; 63: 206-211.

2. Jennette JC, Falk RJ, Bacon PA, et al. Revised International Chapel Hill Consensus Conference Nomenclature of Vasculitides. Arthritis Rheum 2013; 65: 1-11.

3. Langford C. Clinical features and diagnosis of small-vessel vasculitis. Cleve Clin J Med 2012; 79 Suppl 3: S3-S7.

4. Holle JU, Voigt C, Both $\mathrm{M}$, et al. Orbital masses in granulomatosis with polyangiitis are associated with a refractory course and a high burden of local damage. Rheumatology (Oxford) 2013; 52: 875-882.

5. Zalesska-Kręcicka M, Jankowska A, Morawska-Kochman M, Kręcicki T. Objawy laryngologiczne w ziarniniakowatości Wegenera. Otolaryngologia 2004; 3: 162-165.

6. Wódecki M, Brzosko I, Przepiera-Będzak H, Brzosko M. Zajęcie narządu słuchu w ziarniniaku Wegenera. Wiad Lek 2007; 60: 574-577.

7. Trimarchi M, Bussi M, Sinico RA, et al. Cocaine-induced midline destructive lesions - an autoimmune disease? Autoimmun Rev 2013; 12: 496-500.
8. Wiesner O, Russell KA, Lee AS, et al. Antineutrophil cytoplasmic antibodies reacting with human neutrophil elastase as a diagnostic marker for cocaine-induced midline destructive lesions but not autoimmune vasculitis. Arthritis Rheum 2004; 50: 2954-2965.

9. Vega Braga FL, Machado de Carvalho G, Caixeta Guimarães A, et al. Otolaryngological manifestations of Wegener's disease. Acta Otorrinolaringol Esp 2013; 64: 45-49.

10. Ruokonen $\mathrm{H}$, Helve T, Arola J, et al. "Strawberry like" gingivitis being the first sign of Wegener's granulomatosis. Eur J Intern Med 2009; 20: 651-653.

11. Glass EG, Lawton LR, Truelove EL. Oral presentation of Wegener granulomatosis. J Am Dent Assoc 1990; 120: 523-525.

12. Sadlak-Nowicka J, Łaska M, Bochniak M, Weber-Dubaniewicz M. Aspekty stomatologiczne ziarniniaka Wegenera. Dent Med Probl 2003; 40: 417-422.

13. Szczeklik A, Musiał J, Sznajd J. Zapalenia naczyń. In: Zimmermann-Górska I (ed.). Choroby reumatyczne. Interna Szczeklika. Podręcznik chorób wewnętrznych 2013. Wydawnictwo Medycyna Praktyczna, Kraków 2013; 1884-1887.

14. Fauci AS, Haynes BF, Katz P, Wolff SM. Wegener's granulomatosis: prospective clinical and therapeutic experience with 85 patients for 21 years. Ann Intern Med 1983; 98: 76-85.

15. Lee KS, Kim TS, Fujimoto K, et al. Thoracic manifestation of Wegener's granulomatosis: CT findings in 30 patients. Eur Radiol 2003; 13: 43-51.

16. Pełkowska A, Sancewicz-Pach K, Stowiaczek E, Ogarek I. Trudności diagnostyczne w ziarniniaku Wegenera u 15-letniego chłopca. Przegl Pediatr 2005; 35: 174-177.

17. Tomasiewicz B, Rozumek G, Świerkot J. Gruźlica płuc u chorej z ziarniniakowatością z zapaleniem naczyń (dawniej Wegenera) leczonej immunosupresyjnie. Reumatologia 2013; 51: 156-160.

18. Rothschild PR, Pagnoux C, Seror R, et al. Ophthalmologic manifestations of systemic necrotizing vasculitides at diagnosis: retrospective study of 1286 patients and review of the literature. Semin Arthritis Rheum 2013; 42: 507-514.

19. Jiang B, Zhao YY, Wei SH. Granulomatosis with polyangiitis: the relationship between ocular and nasal disease. Ocul Immunol Inflamm 2013; 21: 115-118.

20. Green I, Szyper-Kravitz M, Shoenfeld Y. Parotitis as the presenting symptom of Wegener's granulomatosis: case report and meta-analysis. Isr Med Assoc J 2013; 15: 188-192.

21. Nahlieli O. Wegener's granulomatosis and the salivary glands. Isr Med Assoc J 2013; 15: 178-179.

22. Bray VJ, Hasbargen JA. Prostatic involvement in Wegener's granulomatosis. Am J Kidney Dis 1991; 17: 578-580.

23. Chawla S, Atten MJ, Attar BM. Acute pancreatitis as a rare initial manifestation of Wegener's granulomatosis. A case based review of literature. JOP 2011; 12: 167-169.

24. Allende DS, Booth CN. Wegener's granulomatosis of the breast: a rare entity with daily clinical relevance. Ann Diagn Pathol 2009; 13: 351-357.

25. Małdyk H. Zapalenia małych naczyń. In: Reumatologia kliniczna. Zimmermann-Górska I (ed.). Wydawnictwo Lekarskie PZWL, Warszawa 2009; 662-671.

26. Morales-Angulo C, García-Zornoza R, Obeso-Agüera S, et al. Ear, nose and throat manifestations of Wegener's granuloma- 
tosis (granulomatosis with polyangiitis). Acta Otorinolaringol Esp 2012; 63: 206-211.

27. McCabe C, Jones Q, Nikolopoulou A, et al. Pulmonary-renal syndromes: an update for respiratory physicians. Respir Med 2011; 105: 1413-1421.

28. Papiris SA, Manali ED, Kalomenidis I, et al. Bench-to-bedside review: pulmonary-renal syndromes - an update for the intensivist. Crit Care 2007; 11: 213.

29. Fatma LB, El Ati Z, Lamia R, et al. Alveolar hemorrhage and kidney disease: characteristics and therapy. Saudi J Kidney Dis Transpl 2013; 24: 743-750.

30. de Groot K, Harper L, Jayne DR, et al. EUVAS (European Vasculitis Study Group). Pulse versus daily oral cyclophosphamide for induction of remission in antineutrophil cytoplasmic antibody-associated vasculitis: a randomized trial. Ann Intern Med 2009; 150: 670-680.

31. Jones RB, Tervaert JW, Hauser T, et al. Rituximab versus cyclophosphamide in ANCA-associated renal vasculitis. N Engl J Med 2010; 363: 211-220.

32. Wegener's Granulomatosis Etanercept Trial (WGET) Research Group. Etanercept plus standard therapy for Wegener's granulomatosis. N Engl J Med 2005; 352: 351-361.

33. Silva F, Seo P, Schroeder DR, et al. Solid malignances among etanercept-treated patients with granulomatosis with polyangiitis (Wegener's): long-term followup of a multicenter longitudinal cohort. Arthritis Rheum 2011; 63: 2495-2503.

34. de Menthon M, Cohen P, Pagnoux C, et al. Infliximab or rituximab for refractory Wegener's granulomatosis: long-term follow up. A prospective randomised multicentre study on 17 patients. Clin Exp Rheumatol 2011; 29 (1 Suppl 64): S63-71.

35. Langford CA, Monach PA, Specks U, et al. An open-label trial of abatacept (CTLA4-IG) in non-severe relapsing granulomatosis with polyangiitis (Wegener's). Ann Rheum Dis 2014; 73: 1376-1379.

36. Wygoda A, Rutkowski T, Składowski K, Hejduk B. Low dose radiotherapy as an effective treatment in a patient with a solitary Wegener's granulomatosis resistant to systemic treatment - case report. Contemp Oncol (Pozn) 2013; 17: 107-111. 